\title{
Recycle Household Waste For Resident of Karang Tengah Village Bogor West Java
}

\section{Heni Widyaningsih ${ }^{1}$}

${ }^{1}$ Universitas Negeri Jakarta

\section{ARTICLE INFO}

Article history:

Received: 11th February 2021

Accepted: 25th September 2021

Published: 1st December 2021
Keywords:

Used Cooking Oil, Decorative Candles, Karang Tengah Village Residents

\section{ABSTRACT}

Several local government agencies have made efforts to empower the community in the use of householdwaste, however, due to the vastness and complexity of internal problems resulting not all areas can be reached. The State University of Jakarta requires lecturers to carry out community service or Pengabdian Kepada Masyarakat(PKM) every year. The purpose of PKM is to provide understanding, skills, and enrichment to the community to utilize household waste so that residents of Karang Tengah Village, Bogor, West Java can play an active role in creating economic independence for residents by utilizing waste with the $3 R$ concept (Reuse, Reduce and Recycle). This activity was held on Monday, September 28, 2020, at the Head Office of Karang Tengah Village, Babakan Madang District, Bogor, West Java. The activity was opened by representatives from the Sub-district and attended by around 50 participants. The output of this activity was the publication in the PosKota and Suara Karya newspapers on October 3, 2020, the Activity Poster, and the Tutorial Video on Making Candles from Used Cooking Oil.

How to cite: Widyaningsih, H. (2021). Recycle Household Waste For Resident of Karang Tengah Village Bogor West Java. Jurnal Pemberdayaan Masyarakat Madani (JPMM), 5(2), 281-290. https://doi.org/10.21009/JPMM.005.2.08

* Corresponding Author. 


\section{INTRODUCTION}

Every day, every household produces waste which if not handled properly will harm environmental conditions. Household waste is a waste in the form of liquid and solid from the kitchen, bathroom, and laundry. This waste is not only harmful to the environment but also harmful to human health. Because of this waste, many germs and bacteria can cause many diseases.

Household waste contributes significantly to the level of environmental pollution (Widiyanto, Yuniarno, \& Kuswanto, 2015). Household consumption which continues to increase has an impact on increasing the waste that has been unusable so far. Household waste is mostly in the form of organic waste. Organic waste is a waste that has been discarded and is no longer used, but it can still be reprocessed so that it becomes a product that has utility value and use-value. According to BPS 2018, Indonesia produces $64 \%$ of waste per 2018 and is a second rank as a contributor to plastic waste in the world. The household waste referred to is such as plastic waste that cannot be decomposed for a long time, leftovers from food and beverages and their packaging, leftover cooking oil, and so on. So far, household waste is being disposed of in landfills, which will certainly cause environmental pollution, decrease water quality and will harm public health (Hasibuan, 2016).

However, some people still dump the waste in the rivers and other places. This pattern will cause an impact on environmental damage such as floods, landslides, and air and water pollution. If people understand the use of household waste into a creative product that has benefits and a selling value, it will increase their household income. The additional income will be economic independence and at the macro level will increase the Gross Domestic Product.

\section{LITERATURE}

Based on the problems described above, several solutions can be used to overcome the problem such as the problem of understanding the household waste by providing counseling about recycling waste with 3R, namely Reuse, Reduce, and Recycle. (Abdul-Rahman, 2000). Now the problem of waste treatment is not only in the $3 \mathrm{R}$ treatment process, but the problem of placing waste can also be a solution to minimize household waste (Luluk Kusminah, 2018). Separating the organic and nonorganic waste can reduce the volume of waste due to mixing the two types of waste so that it makes it easier to implement the 3R. Therefore, it is now developing into a waste handler 4R namely Reuse, Reduce, Recycle and Replace.

Second, the problem of handling household waste which keeps increasing every day, namely, namely by providing education and knowledge about making creative products that have economic value, so 


\section{Jurnal Pemberdayaan Masyarakat Madani Volume 5 No 2 December 2021}

that they can increase economic independence for households. Third, by providing this knowledge and skill, it will support government programs in the creative industry sector because of the involvement of local communities to actively participate in creating regional economic independence.

A lot of information regarding business and creativity in creating products has opened the minds of some people who can access this information. There is a lot of information that comes from research and studies regarding the use of waste in a product that can be reused and even has a high selling value. Jelantah Oil or used cooking oil that was previously used only as waste now can be processed into decorative candles or aromatherapy candles, apart from having other functions it also has economic value (Adhani \& Fatmawati, 2017).

In addition to decorative candles or aromatherapy candles, used cooking oil can also be processed into a washing soap or floor cleaning soap (Kusumaningtyas \& Qudus, 2019). Even based on research, now a used cooking oil can be processed into plant fertilizer, animal feed, and can be processed into biofuel. Unfortunately, not many people have made use of this researches, so there is a need for the involvement of academics in disseminating related information to the public, especially those who have not had access to information on household waste treatment such as waste cooking oil.

\section{METHOD}

This community development (PKM) program for this year is carried out using an educational, persuasive, and participatory method or approach. The educational approach, in this case, is by providing information that contains elements of education in the PKM activity program. The persuasive method is to give invitations without coercion to motivate so that the community is motivated to improve their quality of life, while the participatory method is a community service activity that involves the local community playing an active role in implementing the PKM program. The steps area; 


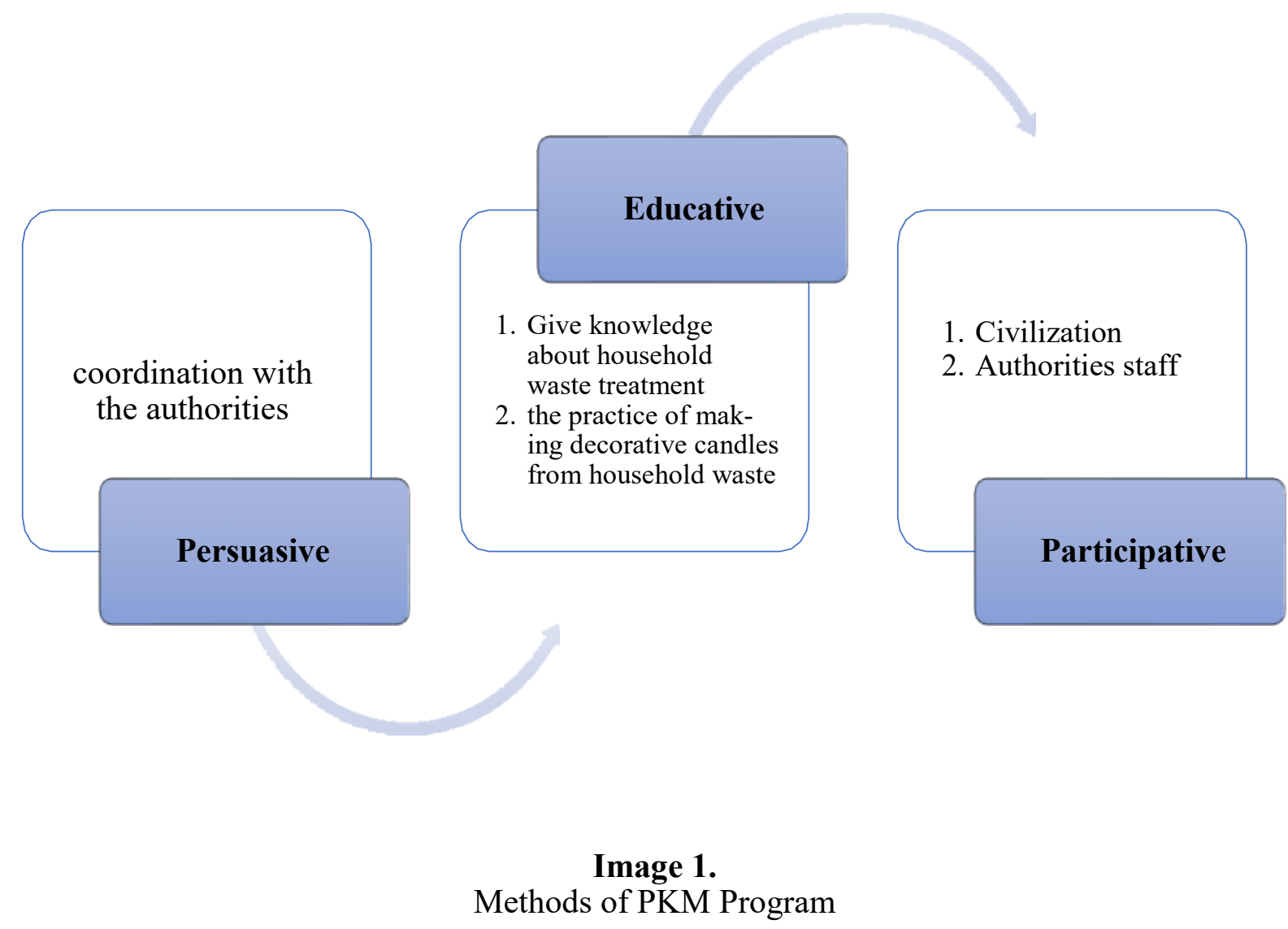




\section{RESULT AND DISCUSSION}

The Preparation for PKM Activity are 1) Coordination with the PKM implementation team, division of workload, and duties of each member of the activity; 2) Contact the involved partners in this activity and ask for official permission to carry out PKM activities; 3) Determine the schedule of activities; 4) Coordination with related parties in the implementation of PKM activities; 5) Preparation and purchase of training materials; and 6) Packaging of materials for training.
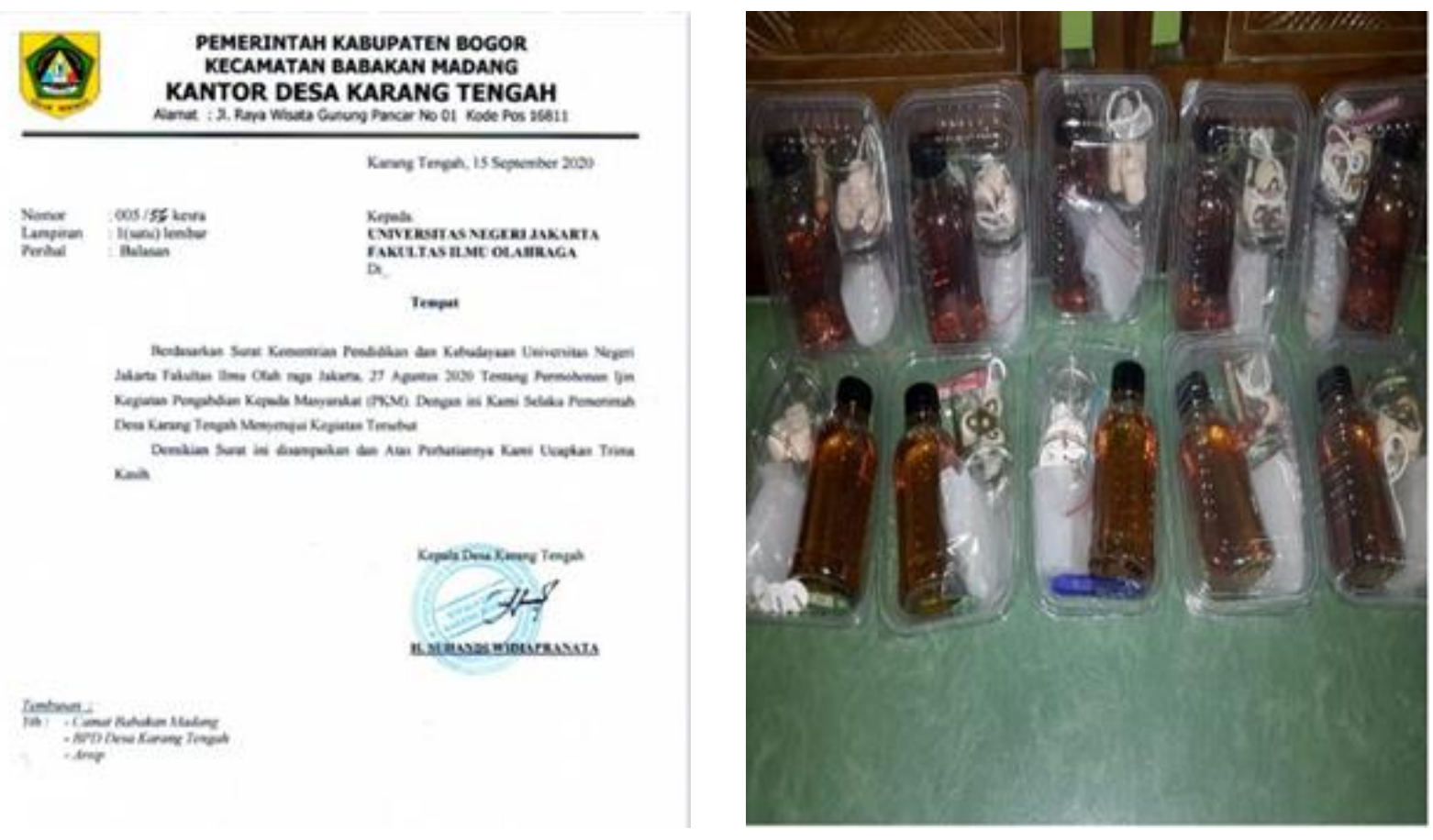

\section{Image 2.}

Permission letter and training materials 


\section{Jurnal Pemberdayaan Masyarakat Madani Volume 5 No 2 December 2021}

The implementation of activities is carried out according to the schedule prepared by the chief executive and members of the PKM activities. The implementation of this activity will be carried out on September 28, 2020, from 08.30 WIB to 16.00 WIB. The training participants for the Training of Making Decorative Candles from Household Waste consisted of housewives and cadres of Karang Tengah Village, Babakan Madang District, Bogor, West Java.

The location for the implementation of this activity is in Karang Tengah Village, Babakan Madang District, Sentul Bogor Regency, West Java. This location was determined with several considerations, such as the number of residents whose job was only to take care of the household. Participants who attended were 50 people consisting of 21 men and 29 women. Most of the various participant professions are housewives, traders, and gardeners. The series of activities began with participant registration and then continued with the opening of the activities by representatives of the Head of Karang Tengah Village and accompanied by the Koorprodi and the head of the activity organizer.

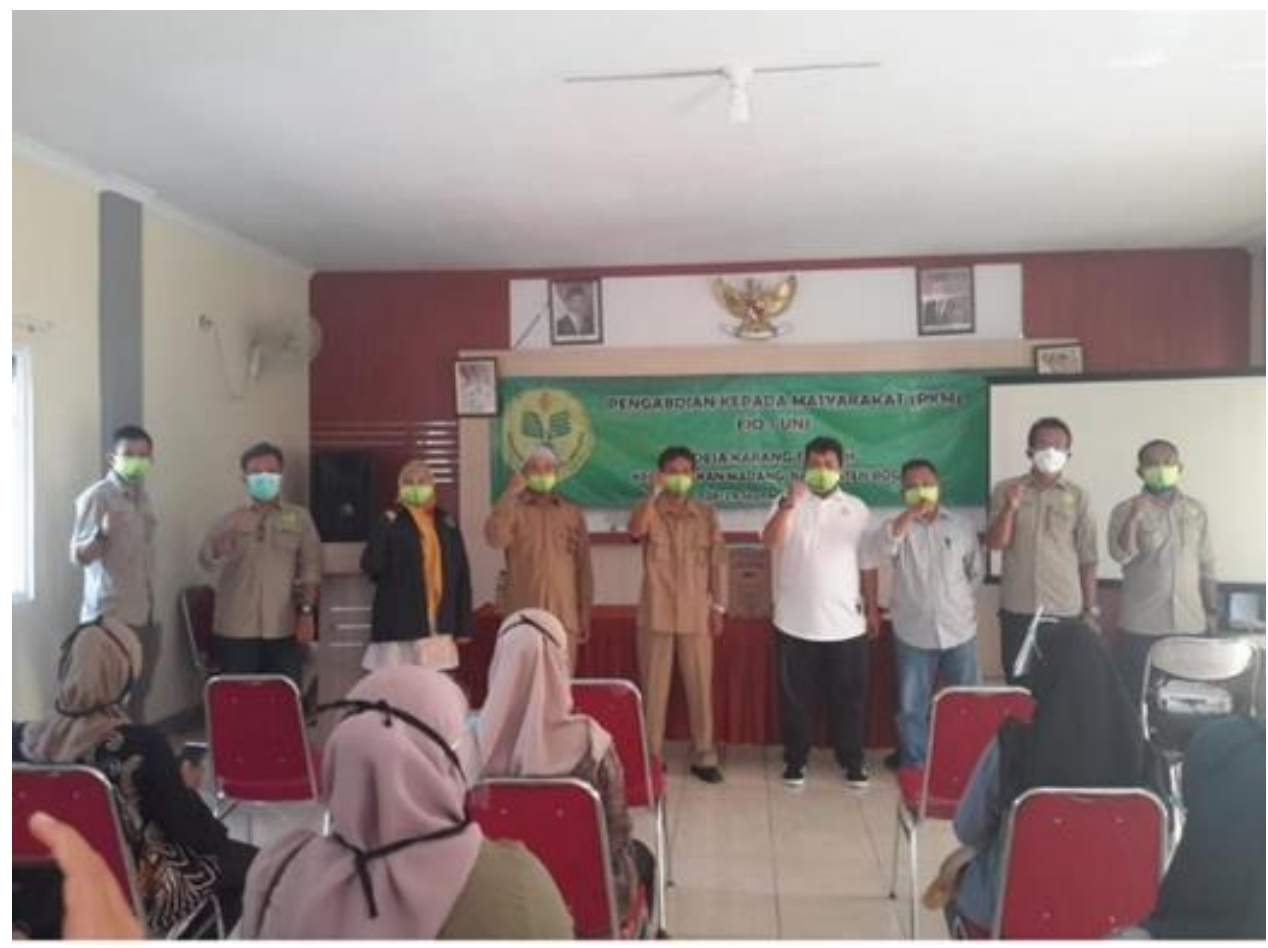

Image 3.

Opening of PKM activities 
PKM activity program consisted of 2 sessions, namely the first session, namely a lecture with the theme of Socialization of the Danger of Usage Household Waste and B3 Waste, then continued with the second theme lecture, namely Utilizing Waste into Useful Products through 3R.
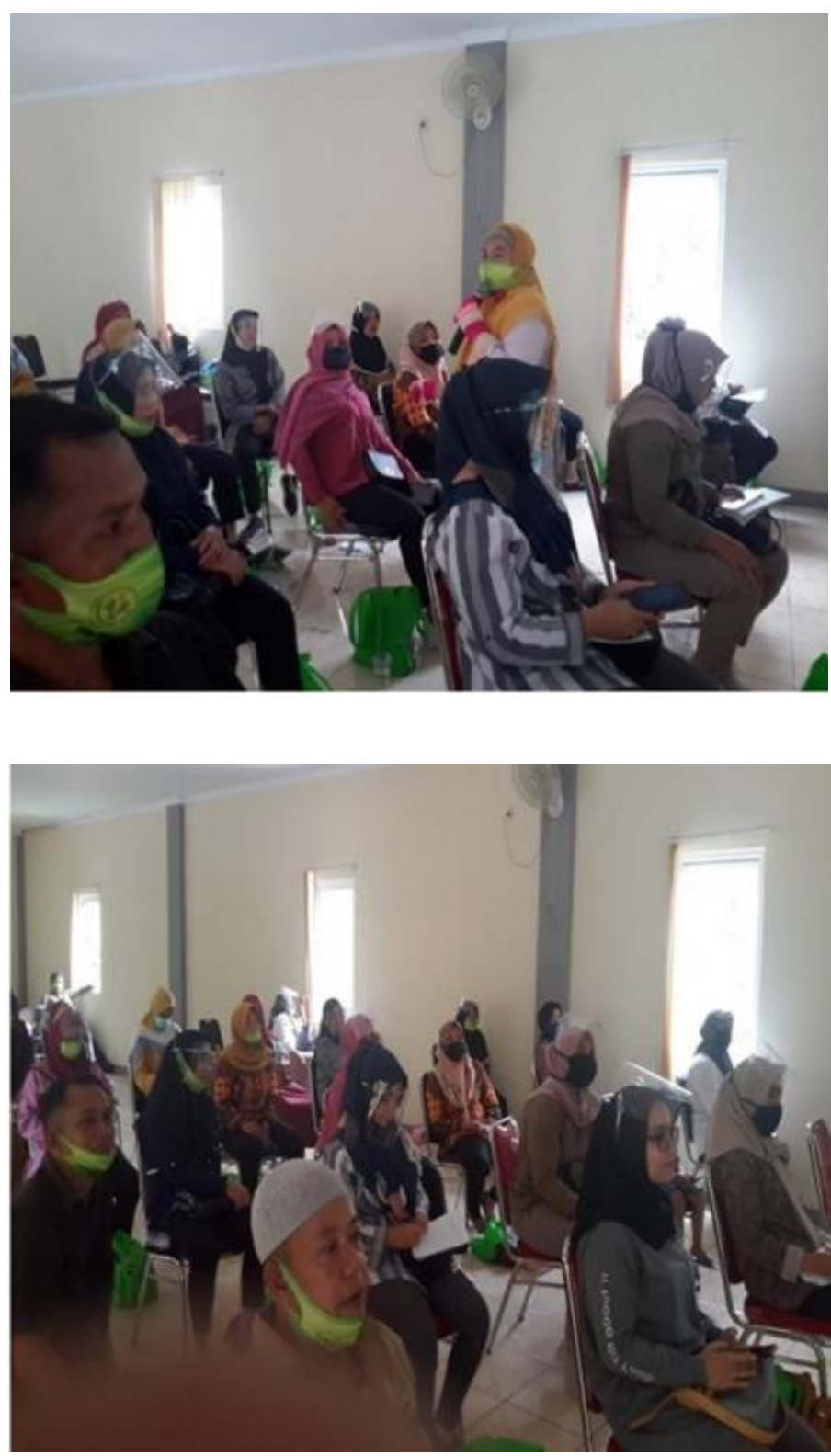

Image 4.

Socialization of Danger and Utilization of Household Waste 


\section{Jurnal Pemberdayaan Masyarakat Madani Volume 5 No 2 December 2021}

The event in the second session was the practice of making products from household waste, namely decorative candles from used cooking oil. The equipment need is a stove, a pan, a spatula, and shot glass. Meanwhile, the material needed is $150 \mathrm{ml}$ of used cooking oil that has been distilled by grinding sugarcane or charcoal, 200 grams of paraffin, 5 drops of perfume essence, and colorful crayon and cotton wick sufficiently. The method of making it is the input used cooking oil and paraffin then heated until melted. Put the shaved into a mixture of oil and paraffin then stir evenly. The next step is to put the oil and paraffin mixture into a shot glass that has been given a cotton wick, let it harden and the decorative candles are packaged in attractive packaging.
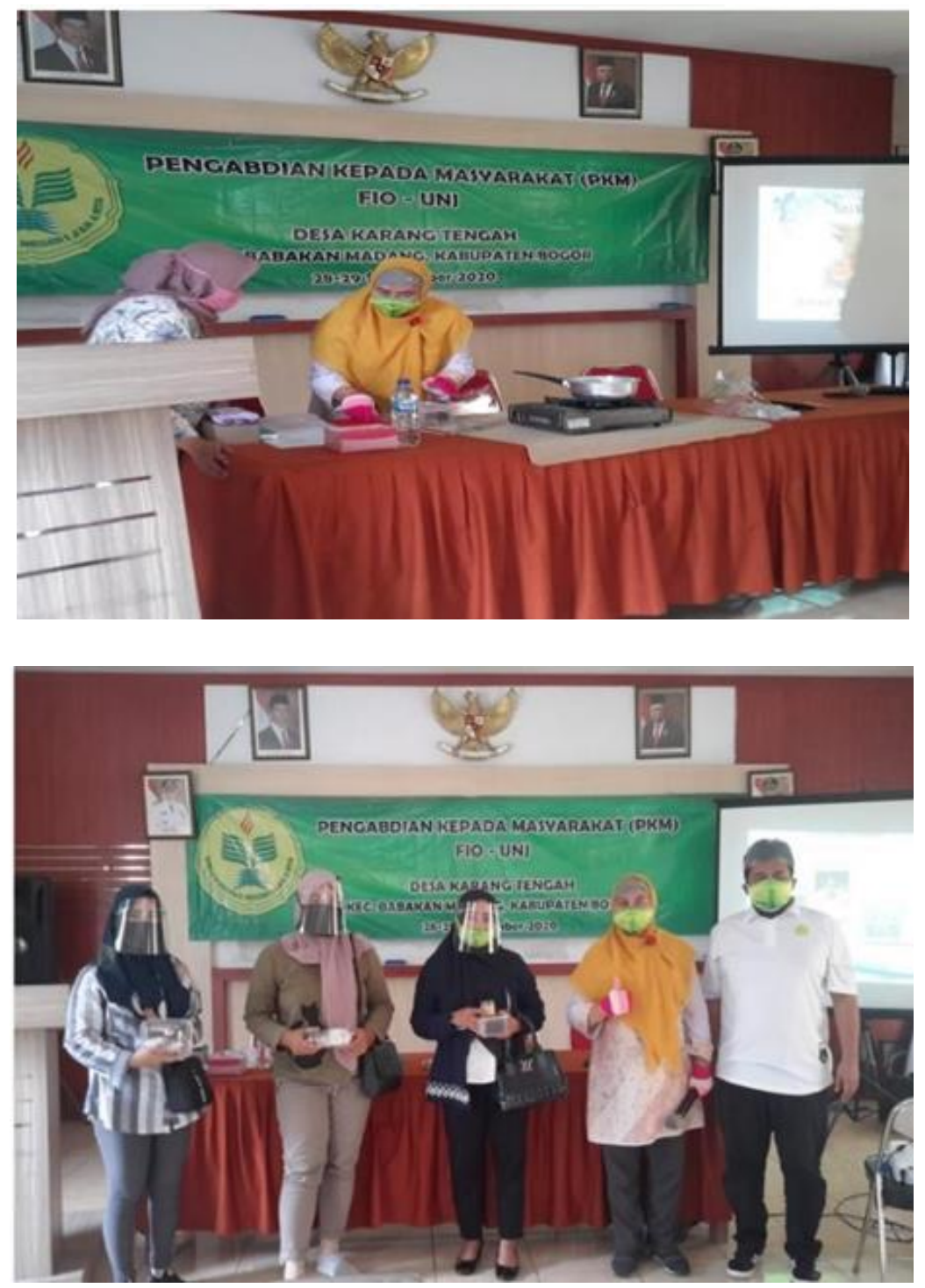

\section{Image 5.}

The Practice of Making Decorative Candles from Used Cooking Oil 


\section{Jurnal Pemberdayaan Masyarakat Madani Volume 5 No 2 December 2021}

The activity ended with a photo of the participants and the trainer.

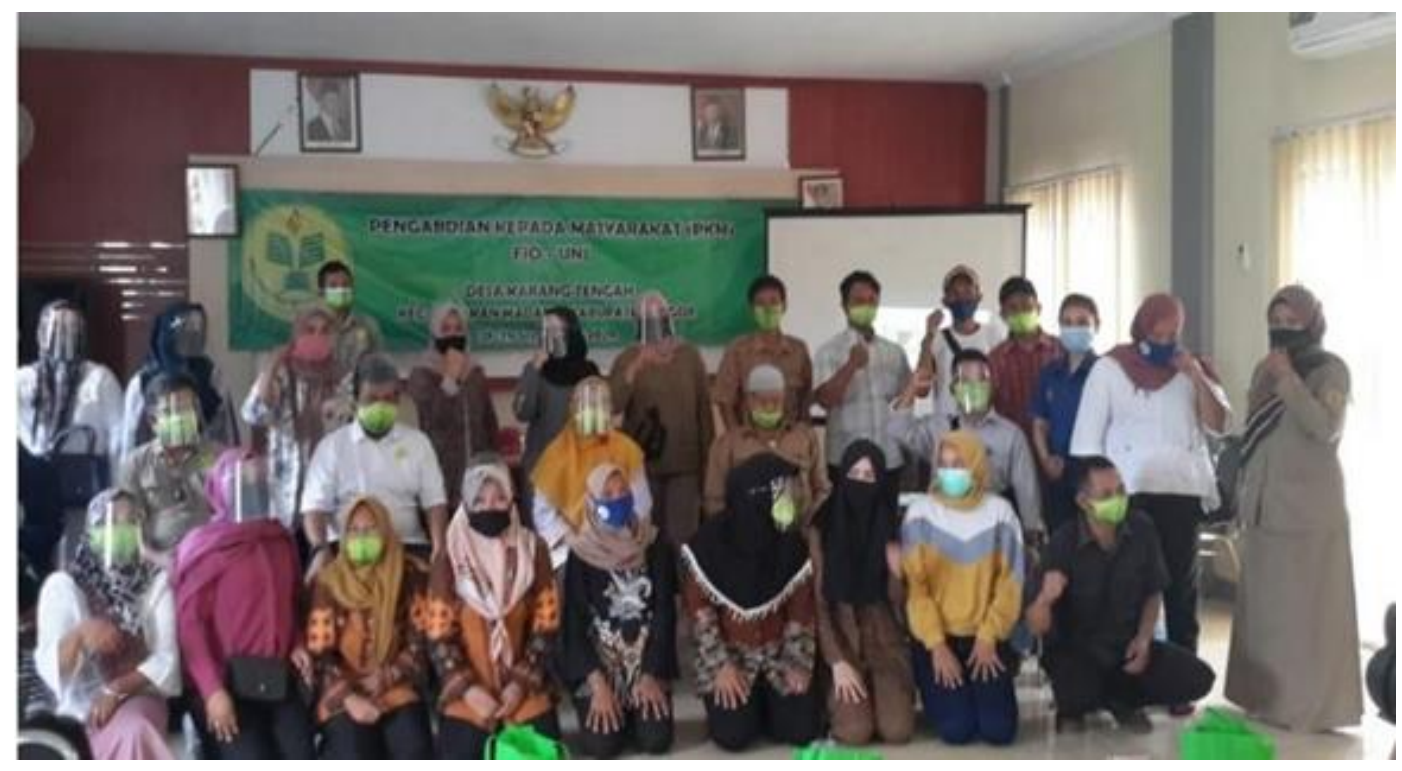

\section{Image 6.}

The Closing of PKM Activities

\section{CONCLUSION AND SUGGESTION}

In general, community service activities provide high benefits to the target audience. Therefore, this activity should be followed by more participants, this is due to the danger of used cooking oil if consumed or thrown away which can create pollution. With the dedication of the community through training in processing waste into products that have economic value, it is hoped that it can increase household income while minimizing the dangers of consuming used cooking oil and minimizing pollution to the environment. 


\section{REFERENCES}

Abdul-Rahman, F. (2000). Reduce, Reuse, Recycle : Alternatives for Waste Management. NM State University, 1-4.

Adhani, A., \& Fatmawati. (2017). JURNAL PENGABDIAN MASYARAKAT BORNEO (e-ISSN: 2579-9797). 40-43.

Hasibuan, R. (2016). Analisis Dampak Limbah/Sampah Rumah Tangga TerhadapPencemaran Lingkungan Hidup. Ilmiah, 04(01), 42-52.

Kusumaningtyas, R. D., \& Qudus, N. (2019). Penerapan Teknologi Pengolahan Limbah Minyak Goreng Bekas Menjadi Sabun Cuci Piring Untuk Pengendalian Pencemaran Dan Pemberdayaan Masyarakat. Jurnal Abdimas, 22(2), 201-208.

Luluk Kusminah, I. (2018). penyuluhan 4R (Reduce, Reise, recyle, replace) dan kegunaanbank sampah sebagai langkah menciptakan lingkungan yang bersih dan ekonomis didesa mojowuku kabupaten gresik. 03(01), 22-28.

Widiyanto, A. F., Yuniarno, S., \& Kuswanto. (2015). Jurnal Kesehatan Masyarakat LANDWATER POLLUTION FROM INDUSTRIAL WASTE AND. Jurnal Kesehatan Masyarakat, 10 (2), 246-254.

https://megapolitan.kompas.com/read/2018/08/19/21151811/indonesia-penyumbang-sampahplastik-terbesar-kedua-di-dunia

Panduan Penelitian dan Pengabdian Kepada Masyarakat, LPPM UNJ, 2020

Pengaruh Limbah Rumah Tangga bagi Lingkungan, Dinas Lingkungan dan Kebersihan Provinsi DKI Jakarta, 2019

Tutorials and Guidelines for making soap from used cooking oil, https:/www.youtube.com/ watch? $=$ Y $53 x p K L s 4 I M$ 